\title{
Incidental Sighting of a Ribbon Seal (Phoca fasciata) in the Western Beaufort Sea
}

\author{
SUE E. MOORE ${ }^{1}$ and EDITH I. BARROWCLOUGH ${ }^{2}$
}

On 29 August 1983, an adult ribbon seal (Phoca fasciata) was seen by one of us (EIB) resting on ice in the western Beaufort Sea $\left(71^{\circ} 41^{\prime} \mathrm{N}, 152^{\circ} 41^{\prime} \mathrm{W}\right.$; Fig. 1), during the course of an aerial survey. The seal did not move from the ice when overflown at $200 \mathrm{~m}$, and was positively identified by its distinctive pelage.

Ribbon seals are commonly found along the ice front in the Bering Sea in winter and early spring, then disperse in late spring as the sea ice breaks up and presumably become solitary and pelagic with poorly known distribution in the summer (Wilke, 1954; Naito and Konno, 1979; Burns, 1970, 1981; Stewart and Everett, 1983). Ribbon seals are rarely seen or taken by Eskimo hunters from coastal villages north of the Bering Strait, and sightings at Wainwright and Point Barrow in the northern Chukchi Sea have been described as "most unusual" (Burns, 1981). Extreme northerly sightings of ribbon seals have been made in the central and western Chukchi Sea (F. Fay, pers. comm. 1984). Burns (1981) reported that extreme ribbon seal dispersal at the southern edge of their effective range is associated with unusual ice conditions. In years of extensive ice in the Bering and Okhotsk Sea, seals are found further south than they normally occur. Although conditions influencing the dispersal of the observed ribbon seal are uncertain, heavy ice conditions reported in the northern Chukchi and western Beaufort seas throughout summer and early autumn in 1983 (Ljungblad et al, 1984) could have been

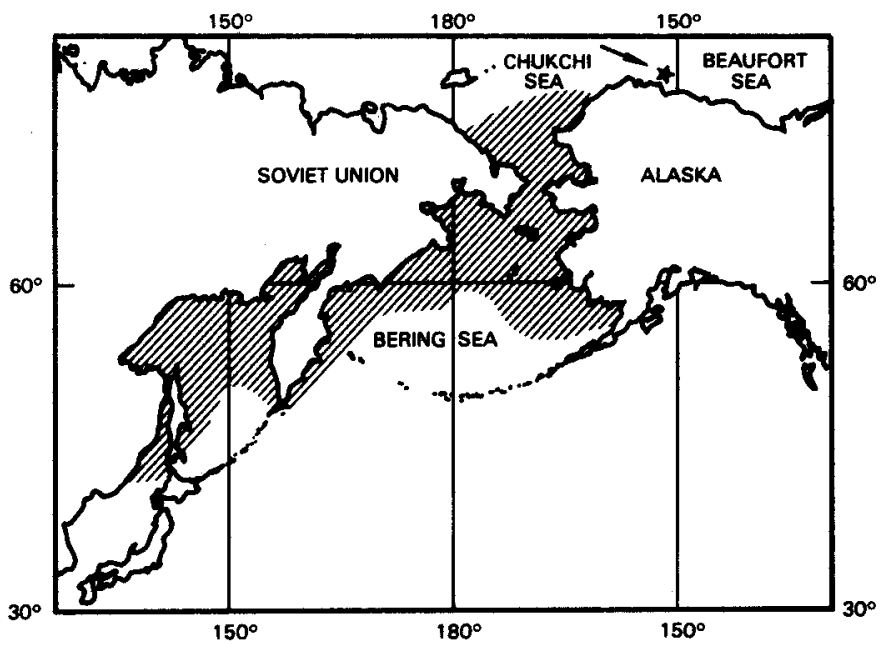

FIG. 1. Approximate location of ribbon seal (Phoca fasciata) seen 29 August 1983 and currently postulated species range (from Burns. 1981). a contributing factor. The observed ribbon seal may have drifted north and east with the ice from the Chukchi Sea during the summer. To our knowledge, this report constitutes the northeasternmost record of a ribbon seal.

\section{ACKOWLEDGEMENTS}

We thank F. Fay for information regarding his unpublished data. We also thank K. Frost and B. Stewart for their expertise and helpful comments on the manuscript.

\section{REFERENCES}

BURNS, J.J. 1970. Remarks on the distribution and natural history of pagophilic pinnipeds in the Bering and Chukchi Seas. Journal of Mammalogy $51: 445-454$.

1981. The ribbon seal. In: Harrison, R.J., and Ridgway, S.H. (eds.). Handbook of Marine Mammals. London: Academic Press, Inc. 89-1 10.

LJUNGBLAD, D.K., MOORE, S.E., and VAN SCHOIK, D.R. 1984. Aerial surveys of endangered whales in the northern Bering, eastern Chukchi and Alaskan Beaufort Seas, 1983. Naval Ocean Systems Center Technical Report 955. 386 p.

NAITO, Y. and KONNO, S. 1979. The post-breeding season distributions of ice-breeding harbour seal (Phoca largha) and ribbon seal (Phoca fasciata) in the southern sea of Okhotsk. Scientific Reports of the Whales Research Institute, Tokyo. 31:105-119.

STEWART, B.S. and EVERETT, W.T. 1983. Incidental catch of a ribbon seal (Phoca fasciata) in the central north Pacific. Arctic 36(4):369.

WILKE, F. 1954. Seals of northern Hokkaido. Journal of Mammalogy 35:218-224. 